\title{
Exploration of Teaching Reform on the Course Automobile Electrical and Electronic Technology
}

\author{
Xiao Mi \\ School of Mechanical and Vehicle Engineering \\ LinYi University \\ Linyi, China \\ mixiao@lyu.edu.cn
}

\begin{abstract}
In order to meet the demand of the innovation and entrepreneurship education, the teaching reform research of the course Automobile Electrical and Electronic Technology is carried out. The new teaching flow is designed and several teaching projects is selected in this paper, besides, assignment book for every project are also designed, including learning objectives, implementation steps, task requirements and examination and evaluation. Many new teaching methods, such as flipped classroom, theory and practice integration are also discussed in this paper. Moreover, the comparison of the students' performance in the two terms' assessment of the course is analyzed. In the end, the results show that the teaching reform of the course Automobile Electrical and Electronic Technology is efficient to cultivate the students' critical thinking, selfdevelopment of knowledge structure, technology understanding, design thinking and leadership skills, and the teaching reform of the course could greatly improve the innovation and entrepreneurship teaching performance.
\end{abstract}

Keywords-Teaching mode; Teaching flow; Teaching method; Automobile electrical and electronic technology

\section{INTRODUCTION}

With the rapid development of the new industry revolution, the engineering education demands an all-rounded reform. The aim of the qualified engineering education must be the training of critical thinking, self-development of knowledge structure, technology understanding, design thinking and leadership skills The critical thinking is a kind of attitude of doubt. It means the students should not trust other people's thought or theory easily. The critical thinking is a kind of attitude of curiosity. It means the students should focus on every detail and be good at finding problems which no one has found. The critical thinking is also a kind of attitude of cautious. It means that everything should be supported by the reliable proof. In order to develop students' critical thinking, the teaching reform must be changed. The classroom teaching mode should be shifted to "communication-query-debate" mode from "only listen" mode. The ability of self-development of knowledge structure is based on the fewer but better teaching content, the strict assessment, and the strengthening of the basic knowledge. The technology understanding depends on whether the students master the modern technique tools. Design thinking is peopleoriented thinking in short. Therefore, design thinking should also be integrated into the engineer education. The leadership skills are indispensable among the extraordinarily ability of a

This research was supported by the Innovation and Entrepreneurship Education Demonstration Course Project of LinYi University, Shandong, China, in 2017. modern engineer.

The teaching reform of the course Automobile Electrical and Electronic Technology has been performed for many years. Many teaching methods and ideas, such as project teaching method, flipped classroom, theory and practice integration, have been applied on the teaching reform practice. The new teaching process design is also made to meet the demands of the innovation and entrepreneurship education.

\section{TEACHING METHOD REFORM}

\section{A. Project teaching}

Project teaching is also called behavior-oriented teaching. It is usually based on the development of the student. It helps to enhance the ability of explore and practice of the students. It is a teaching activity performed by both students and teachers [1] It could improve the study interest and innovation ability of the students. Moreover, it also could enhance students' analysis ability, strain capacity, communication ability and cooperation ability.

Unlike the traditional teaching method, the project teaching is bidirectional rather than unidirectional. The stimulation way is based on the inner motivation and lasting rather than forced and unabiding [2].

With the rapid development of the automobile technology, the electrical and electronics system of the automobile is becoming more and more complex. The control circuit of the automotive components is more complicated, such as automotive head light control system, infrared rain-sensing wipers control system, button start control system and automatic car backing control system. It requires the automobile professional design and maintenance technician to master fund of knowledge of automobile electrical and electronics system and diagnosis technology of the latest automobile components. The strong abstract thinking ability, logical analyzing ability and self-learning ability are also necessary for the automobile technician.

Therefore, in order to meet the requirement of the rapid development of automobile electrical and electronic technology and also obey the principle of strengthening the basic knowledge, eleven projects are selected as the basic content of the project teaching. They are automobile alternator assemble, disassemble and diagnosis, automobile starter assemble, disassemble and diagnosis, automobile ignition system 
assemble, disassemble and diagnosis, automobile lighting and signal system diagnosis, automobile auxiliary electrical equipment system diagnosis, engine manage system diagnosis, automobile automatic transmission diagnosis, automobile electric power steering diagnosis, automobile anti-lock braking system diagnosis, automobile electronic control suspension system diagnosis, automobile entire circuitry diagnosis.

The project design of the course is demonstrated in Table I.

TABLE I. PROJECT Design OF COURSE

\begin{tabular}{|c|c|c|}
\hline Project Number & Project Name & Learning Objectives \\
\hline QD1 & $\begin{array}{l}\text { Automobile Alternator Assemble, Disassemble and } \\
\text { Diagnosis }\end{array}$ & $\begin{array}{l}\text { 1. The Assemble and Disassemble of the Automobile Alternator } \\
\text { 2. The Operation Principal and Basic Structure of the Automobile } \\
\text { Alternator } \\
\text { 3. The Repair and Diagnosis method of the Automobile Alternator }\end{array}$ \\
\hline QD2 & $\begin{array}{l}\text { Automobile Starter Assemble, Disassemble and } \\
\text { Diagnosis }\end{array}$ & $\begin{array}{l}\text { 1. The Assemble and Disassemble of the Automobile Starter } \\
\text { 2. The Operation Principal and Basic Structure of the Automobile Starter } \\
\text { 3. The Repair and Diagnosis method of the Automobile Starter }\end{array}$ \\
\hline QD3 & $\begin{array}{l}\text { Automobile Ignition System Assemble, Disassemble } \\
\text { and Diagnosis }\end{array}$ & $\begin{array}{l}\text { 1. The Assemble and Disassemble of the Automobile Ignition System } \\
\text { 2. The Operation Principal and Basic Structure of the Automobile } \\
\text { Ignition System } \\
\text { 3. The Repair and Diagnosis method of the Automobile Ignition System }\end{array}$ \\
\hline QD4 & Automobile Lighting and Signal System Diagnosis & $\begin{array}{l}\text { 1. The Use and Adjustment method of the Automobile Lighting and } \\
\text { Signal System } \\
\text { 2. The Operation Principal and Basic Structure of the Automobile } \\
\text { Lighting and Signal System } \\
\text { 3. The Repair and Diagnosis method of the Automobile Lighting and } \\
\text { Signal System }\end{array}$ \\
\hline QD5 & $\begin{array}{l}\text { Automobile Auxiliary Electrical Equipment System } \\
\text { Diagnosis }\end{array}$ & $\begin{array}{l}\text { 1. The Use and Adjustment method of the Automobile Auxiliary } \\
\text { Electrical Equipment System } \\
\text { 2. The Operation Principal and Basic Structure of the Automobile } \\
\text { Auxiliary Electrical Equipment System } \\
\text { 3. The Repair and Diagnosis method of the Automobile Auxiliary } \\
\text { Electrical Equipment System }\end{array}$ \\
\hline QD6 & Engine Manage System Diagnosis & $\begin{array}{l}\text { 1. The Use and Adjustment method of the Engine Manage System } \\
\text { 2. The Operation Principal and Basic Structure of the Engine Manage } \\
\text { System } \\
\text { 3. The Repair and Diagnosis method of the Engine Manage System }\end{array}$ \\
\hline QD7 & Automobile Automatic Transmission Diagnosis & $\begin{array}{l}\text { 1. The Use and Adjustment method of the Automobile Automatic } \\
\text { Transmission } \\
\text { 2. The Operation Principal and Basic Structure of the Automobile } \\
\text { Automatic Transmission } \\
\text { 3. The Repair and Diagnosis method of the Automobile Automatic } \\
\text { Transmission }\end{array}$ \\
\hline QD8 & Automobile Electric Power Steering Diagnosis & $\begin{array}{l}\text { 1. The Use and Adjustment method of the Automobile Electric Power } \\
\text { Steering } \\
\text { 2. The Operation Principal and Basic Structure of the Automobile } \\
\text { Electric Power Steering } \\
\text { 3. The Repair and Diagnosis method of the Automobile Electric Power } \\
\text { Steering }\end{array}$ \\
\hline QD9 & Automobile Anti-lock Braking System Diagnosis & $\begin{array}{l}\text { 1. The Use and Adjustment method of the Automobile Anti-lock Braking } \\
\text { System } \\
\text { 2. The Operation Principal and Basic Structure of the Automobile Anti- } \\
\text { lock Braking System } \\
\text { 3. The Repair and Diagnosis method of the Automobile Anti-lock } \\
\text { Braking System }\end{array}$ \\
\hline QD10 & $\begin{array}{l}\text { Automobile Electronic Control Suspension System } \\
\text { Diagnosis }\end{array}$ & $\begin{array}{l}\text { 1. The Use and Adjustment method of the Automobile Electronic } \\
\text { Control Suspension System } \\
\text { 2. The Operation Principal and Basic Structure of the Automobile } \\
\text { Electronic Control Suspension System } \\
\text { 3. The Repair and Diagnosis method of the Automobile Electronic } \\
\text { Control Suspension System }\end{array}$ \\
\hline QD11 & Automobile Entire Circuitry Diagnosis & $\begin{array}{l}\text { 1. The Reading and Circuit Diagnosis of Different Automobile } \\
\text { Manufacturer Circuit Map } \\
\text { 2. The Operation Principal and Basic Structure of Different Automobile } \\
\text { Circuit } \\
\text { 3. The Repair and Diagnosis method of Different Automobile Circuit }\end{array}$ \\
\hline
\end{tabular}

The project teaching is generally composed of four stages including project task setting, making project plan, implementation of the project, project evaluation and summary [3]. Firstly, one or more project tasks have to be set by the teacher according teaching content, teaching objectives, teaching conditions and demands of actual production. Secondly, the students have to make the project plan according to the requirement of project task. Then, after a clear division 
of labor in the team, the project comes into operation. At last, the students and teacher discuss together on the problems during the implementation of project.

The concrete implement process of project teaching could be discussed by the example of the project QD4 Automobile Lighting and Signal System Diagnosis. The students are divided into four to six teams by the teacher. Then the project task is assigned. The assignment book is demonstrated in Table II.

Then the project is carried out by all the students according the assignment book.

TABLE II.

ASSIGNMENT BOOK

\begin{tabular}{|c|l|}
\hline Project Name & Automobile Lighting and Signal System Diagnosis \\
\hline \multirow{2}{*}{ Learning Objectives } & $\begin{array}{l}\text { 1. The Use and Adjustment method of the Automobile Lighting and Signal System } \\
\text { 2. The Operation Principal and Basic Structure of the Automobile Lighting and Signal System } \\
\text { 3. The Repair and Diagnosis method of the Automobile Lighting and Signal System }\end{array}$ \\
\hline Implementation Step & $\begin{array}{l}\text { 1. The Representation of the Project Task Objective and Requirement and assignment of the task. } \\
\text { 2. Team Discussion. Analyze the circuit map of the lighting and signal system. Connect the head }\end{array}$ \\
\hline \multirow{5}{*}{ Implementation Step } & $\begin{array}{l}\text { Lights and signal lights with wiring according to the circuit map. Diagnose the cause of head light not bright, short circuit, head } \\
\text { light dim and signal light failure. Make the project plan. } \\
\text { 3. The Implementation of the project according to the plan. } \\
\text { 4. The Demonstration of the Learning Outcomes and Self-assessment. } \\
\text { 5. The mutual assessment and summary. }\end{array}$ \\
\hline \multirow{5}{*}{ Task Requirement } & $\begin{array}{l}\text { 1. Connect the Automobile Lighting and Signal System Correctly } \\
\text { 2. Students could diagnose common fault of the Automobile Lighting and Signal System Correctly } \\
\text { 3. The proper use of various testing instruments }\end{array}$ \\
\hline \multirow{5}{*}{$\begin{array}{l}\text { 1. Every team would demonstrate their wiring connection of the lighting and signal system and explain in detail about how to } \\
\text { diagnose the common fault of the lighting and signal system. } \\
\text { 2. Every team assesses and summarizes their own performance. Think about whether they finish the task, are there some problems, } \\
\text { how to improve and what experience they get. } \\
\text { 3. All the teams carry out mutual assessment. Point out each team's advantage and disadvantage and make contrast and } \\
\text { comparison. Communicate and learn from each other. } \\
\text { 4. The Evaluation by Teacher. On one hand, it is based on every team's performance in the subject implementation. On the other } \\
\text { hand, it is also based on the performance of team members cooperation, self-assessment and mutual assessment and team learning } \\
\text { outcomes demonstration. } \\
\text { 5. The Summary of the Project Learning Process by Teacher. The teacher would give both the praise and criticism based on every } \\
\text { team's overall performance. }\end{array}$} \\
\hline
\end{tabular}

\section{B. Flipped Classroom}

The new classroom teaching process is proposed and practiced. It includes seven teaching steps: students prepartion before class, classroom questioning, question explanation, group discussion, teacher's lecturing, group practice and classroom testing.

The students have to preview the learning materials in the guided learning plan, teaching courseware and teaching video with the help of learning objectives, key and difficult points and learning methods which is included in the guided learning plan. They may learn individually, go to the workshop to practice or discuss in group. To complete the preview assignment, the students also have to finish the essay questions, assignment and multiple choice questions and discuss their answers in group. Then they feed the common questions back to teacher [4].
The classroom teaching is carried out in the workshop. The first step of the class is classroom questioning. It is to check the students' preview effect. To solve the common questions that all the groups feed back to teacher during the preview, the step of question explanation is designed next to the classroom question. The step of classroom discussion helps the students to think the deeper question which is related to the key and difficult points [5]. The step of teacher's lecturing is to summarize the students' performance in the previous steps and knowledge points. The step of group practice combines the theory with practice. To assess the learning outcome, classroom testing is designed to be the last step.

The secondary learning is organized after class if some groups don't pass the classroom test. The teaching flow is shown in figure 1. 


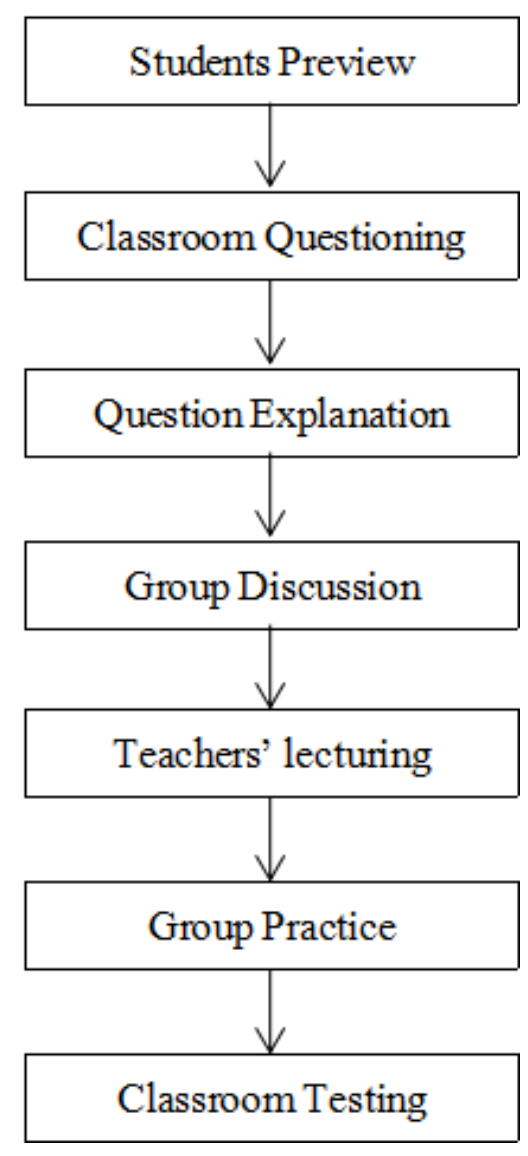

Fig. 1. Flipped classroom teaching flow

To make the flipped classroom more effectively, some measures and suggestions could be adopted from our teaching experience.

- Establishment of a research team of teaching reform. All the resources need to be combined together to establish a professional flipped classroom research team by the university or school [6]. Every team member has the responsibility of different course and shares the respective research results to help the whole team to improve the flipped classroom effectiveness.

- The fair teacher evaluation mechanism. The teaching mode reform has to be included in the teacher's academic assessment. It enhances the teacher's motivation to improve flipped classroom effectiveness.

What's more, the flipped classroom has to be combined with other teaching methods to achieve its best teaching effectiveness.

\section{COMPARISON OF STUDENTS' PERFORMANCE}

In order to verify the effect of the teaching reform, we perform an experiment in the course Automobile Electrical and Electronics technology in two terms. In the first term, the course was taught in the tradition way without any blended learning mode and new teaching method. In the first term, the teachers were usually the focus of a lesson, almost all the lessons are focused on an explanation of teaching content by the way of lecturing. In the second term, the course was taught by using both the project teaching and new seven steps teaching flow mentioned above. The final exam score of the course in two terms is shown in figure 2.

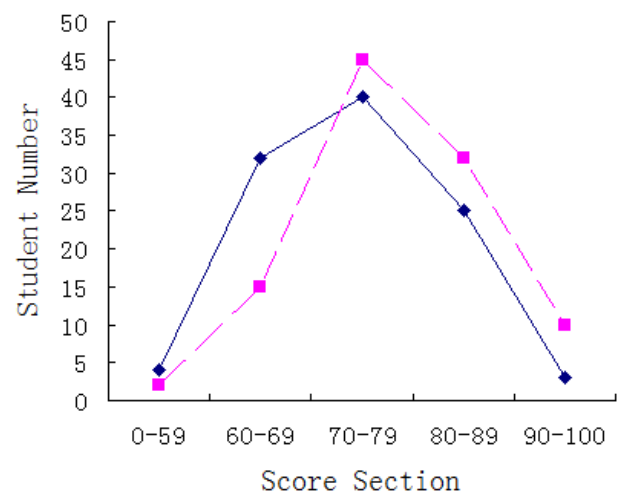

Fig. 2. Comparison of students' performance

In the figure 2, the full line curve is the final exam score distribution of the first term and the dotted line curve is of the second term's. From the figure 2, we can easily find that the students shift to higher score section in the second term. It means that our teaching reform is proved to be very effective to improve the students' learning outcomes.

\section{CONCLUSION}

The teaching reform research of the course Automobile Electrical and Electronic Technology was carried out. The new seven-step teaching flow was designed and eleven teaching projects were selected. The assignment book is designed for every project. The comparison of the students perform in the two terms' assessment of the course shows that the teaching reform of the course Automobile Electrical and Electronic Technology is efficient to cultivate the students' critical thinking, self-development of knowledge structure, technology understanding, design thinking and leadership skills. And the teaching reform of the course improved greatly on the innovation and entrepreneurship teaching perform.

\section{ACKNOWLEDGMENT}

This research was supported by the Innovation and Entrepreneurship Education Demonstration Course Project of LinYi University, Shandong, China, in 2017. 


\section{REFERENCES}

[1] X. Mi, and P. Chen, "Research on Project Teaching of the Course Automobile Electronic and Electrical Equipment," Advances in Computer Science Research, vol. 25, pp. 528-531, September 2015

[2] J. Wang, Y. Shen, and H. Sun, "Project Teaching Practice on Undergraduate Filed Subject," Modern Education Science, vol. 11, pp. 52-66, November 2012.

[3] J. Mao, "Experiences on Project Teaching," China Education Innovation Herald, vol. 21, pp. 63, July 2007.

[4] X. Mi, "Research on Classroom Teaching Mode Reform of Automobile Service Engineering Program," Advances in Social Science, Education and Humanities Research, vol. 157, pp. 350-353, November 2017.

[5] W. Zhang, and X. Ma, "Flipped Classroom Teaching Design based on Micro-Course Online Video," Educational Information Technology, vol. 3, pp. 3-9, March 2015.

[6] Jennifer Moffett, and Aillen Mill, "Evaluation of the Flipped Classroom Approach in a Veterinary Professional Skills Course," Advances in Medical Education and Practice, vol. 10, pp. 415-425, October 2014. 